\title{
MULTILEVEL LOGISTIC REGRESSION ANALYSIS \\ ON THE EFFECTIVENESS OF CHRONIC DISEASE MANAGEMENT PROGRAM IN IMPROVING "CERDIK" HEALTHY BEHAVIOR FOR HYPERTENSIVE PATIENTS
}

\author{
Tri Puji Pangesti'), Didik Gunawan Tamtomoº, Bhisma Murti' ${ }^{\text {) }}$ \\ 1)Masters Program in Public Health, Universitas Sebelas Maret \\ 2)Faculty of Medicine, Universitas Sebelas Maret
}

\begin{abstract}
Background: The chronic disease management program (prolanis) was established in Indonesia to help people achieve optimal quality of life with cost-effective and efficient health services. The user targets were national health insurance participants who suffer from chronic disease, including hypertension and diabetes mellitus. This study aimed to examine the effectiveness of prolanis in improving "CERDIK" healthy behavior for hypertensive patients.

Subjects and Method: A cross sectional study was carried out at 25 community health centers in Gunungkidul, Yogyakarta, Indonesia, from January to February 2020. A sample of 200 hypertensive patients were selected by stratified random sampling. The dependent variable was healthy behavior. The independent variables were sex, education, family support, peer support, and prolanis. The data were collected by questionnaire and analyzed by a multiple logistic regression run on Stata 13.

Results: Healthy behavior in patients with hypertension increased with $(b=1.95 ; 95 \% \mathrm{CI}=$ 0.76 to $3.16 ; \mathrm{p}=0.001)$, participative in prolanis $(\mathrm{b}=3.93 ; 95 \% \mathrm{CI}=2.42$ to $5.44 ; \mathrm{p}<0.001)$, strong family support $(\mathrm{b}=1.38 ; 95 \% \mathrm{CI}=0.09$ to $2.67 ; \mathrm{p}=0.035)$, strong peer support $(\mathrm{b}=$ $0.50 ; 95 \% \mathrm{CI}=-0.81$ to $1.91 ; \mathrm{p}=0.427)$, and female $(\mathrm{b}=0.89 ; 95 \% \mathrm{CI}=-0.35$ to $2.13 ; \mathrm{p}=0.160)$. Community health center had contextual effect on healthy behavior with ICC $=27 \%$.

Conclusion: Healthy behavior in patients with hypertension increases with high education, participative in prolanis, strong family support, strong peer support, and female. Community health center has contextual effect on healthy behavior.
\end{abstract}

Keywords: chronic disease management program, cerdik health behavior, hypertension.

\section{Correspondence:}

Tri Puji Pangesti. Masters Program in Public Health, Universitas Sebelas Maret. Jl. Ir. Sutami 36A, Surakarta 57126, Central Java. Email: tripujipangesti8@gmail.com. Mobile: o82312657779.

The $7^{\text {th }}$ International Conference on Public Health Solo, Indonesia, November 18-19, 2020|359 https://doi.org/10.26911/the7thicph.04.44 